\title{
How mycorrhizal associations and plant density influence intra- and inter-specific competition in two tropical tree species: Cabralea canjerana (Vell.) Mart. and Lafoensia pacari A.St.-Hil.
}

\author{
Aline Danieli-Silva $\cdot$ Alexandre UhImann . \\ José Vicente-Silva · Sidney Luiz Stürmer \\ Received: 30 June 2009 / Accepted: 1 October 2009 \\ (c) Springer Science + Business Media B.V. 2009
}

\begin{abstract}
Arbuscular mycorrhizal fungi (AMF) associations benefit host plants due to increased ability to obtain resources and hence may influence competitive interactions. Here we experimentally examine growth in Cabralea canjerana and Lafoensia pacari at different densities and with and without AMF. In the density treatment pots had either six or 12 individuals. Half of each treatment was innoculated with AMF and the other half was not. The proportion
\end{abstract}

Responsible Editor: Angela Hodge.

A. Danieli-Silva ( $(<)$

Programa de Pós-graduação em Ecologia e Conservação,

Universidade Federal do Paraná,

Caixa Postal 19031, CEP: 81531-980 Curitiba, PR, Brazil

e-mail: aline.ecologia $(a)$ gmail.com

\section{A. Uhlmann}

Empresa Brasileira de Pesquisa Agropecuária

EMBRAPA Amapá,

Rodovia Juscelino Kubitschek, 2.600 ,

Clep 68903-419 Macapá, AP, Brazil

J. Vicente-Silva

Programa de Pós-graduaçào em Ecologia,

Universidade Federal do Rio Grande do Sul,

Caixa Postal 15007, CEP: 91540-000 Porto Alegre, RS,

Brazil

\section{S. L. Stürmer}

Departamento de Ciências Naturais,

Universidade Regional de Blumenau,

Caixa Postal 1507, CEP: 89010-971 Blumenau, SC, Brazil of each species in each pot was also varied. The AMF did not apparently influence interspecific competitive interactions because growth was similar in both treatments. However, intra-specific competition was very strong in $C$. canjerana while more moderate in L. pacari and both were influenced by the presence of the AMF. The AMF-Cabralea canjerana interaction was parasitic, while AMF-L. pacari interactions were mutualistic. Thus, dependence upon AMF and intraspecific interactions that result as a consequence of that dependence varies among species and may be an important influence in community structure.

Keywords Arbuscular mycorrhizal fungi .

Competition - Parasitism - Relative yields .

Replacement series

\begin{tabular}{|c|c|}
\hline Abbreviations & \\
\hline $\mathrm{AMF}$ & arbuscular mycorrhizal fungi \\
\hline ANOVA & analysis of variance \\
\hline $\mathrm{C}$ & carbon \\
\hline C. canjerana & Cahralea canjerana \\
\hline $\mathrm{Cii}$ & $\begin{array}{l}\text { development (biomass) of species } i \\
\text { when grown in monoculture }\end{array}$ \\
\hline Cij & $\begin{array}{l}\text { development (biomass) of species } i \\
\text { when grown in mixture with species } j\end{array}$ \\
\hline $\mathrm{C} j i$ & $\begin{array}{l}\text { development (biomass) of species } j \\
\text { when grown in mixture with species } i\end{array}$ \\
\hline $\mathrm{C} j j$ & $\begin{array}{l}\text { development (biomass) of species } j \\
\text { when grown in monoculture }\end{array}$ \\
\hline
\end{tabular}




$\begin{array}{ll}\text { FURB } & \text { Universidade Regional de Blumenau } \\ \mathrm{H}_{2} \mathrm{O}_{2} & \text { hydrogen peroxide } \\ \mathrm{HCl} & \text { Hydrochloric acid } \\ \mathrm{KOH} & \text { potassium hydroxide } \\ \text { L. pacari } & \text { Lafoensia pacari } \\ \mathrm{M} & \text { mycorrhizal plants } \\ \mathrm{NM} & \text { non-mycorrhizal plants } \\ \mathrm{P} & \text { phosphorus } \\ \mathrm{RY} & \text { relative yields } \\ \text { TD } & \text { total density }\end{array}$

\section{Introduction}

Relationships between plants and their arbuscular mycorrhizal fungi (AMF) can influence how those plants interact with others, such as in interspecific competition (Hartnett et al. 1993; Hetrick et al. 1994; Zobel and Moora 1995; van der Heijden et al. 2003). This is due to the activities of the fungus with respect to the acquisition by the plant of nutrients and water (Chapin et al. 1994; van der Heijden 2002). Thus, if the fungus association benefits the plant by facilitating nutrient acquisition, the plant can become a better competitor (Tilman 1982).

Phosphorus (P) is an example of an essential macronutrient for plants, but which is not very mobile within the soil and therefore may often be limiting (Marschner 1995; Allen 1996) and plant-fungal associations may often improve the rate of uptake for the plant (Smith and Read 1997; Ozinga et al. 1997; Dodd et al. 2000; Jones and Smith 2004). Additionally, plant-fungal associations increase water uptake for the plant (Wright and Upadhyaya 1998), reduce uptake of heavy metals (Sylvia and Williams 1992; Oliveira et al. 2005), improve defense against pathogens (Newsham et al. 1995) and may influence plant structural architecture that also influence nutrient acquisition (Jones and Smith 2004). Such interactions may often benefit the plant in a variety of ways, thereby increasing the competitive ability of the plant (Hartnett and Wilson 2002; Kytöviita et al. 2003). Consequently, this competitive benefit may favor some species over others (Allen and Allen 1990; Pedersen and Sylvia 1996; Sylvia et al. 2001).

Plants are quite variable in their response to fungal associations (Thingstrup et al. 1998; Khalil et al. 1999) and so the role of the fungus as a mediator of competitive interactions should occur when the plants vary widely in their response to the fungus. For example, mycorrhizal grasses are strongly favored in competitive interactions over those non-mycorrhizal (Hartnett et al. 1993; Hetrick et al. 1994).

Thus, AMF associations can influence competitive interactions (van der Heijden 2002; Hart et al. 2003; van der Heijden et al. 2003) and influence the maintenance of plant diversity in communities (Oliveira et al. 2006). Most studies of these associations, however, have used grasses as the model species and whether similar interactions occur in tree species is still unknown in most cases. In tropical trees the benefit due to AMF may be large, because nutrients, such as phosphorus, are often not easily available to the plants, especially in deforested areas (Carnciro et al. 1996). Thus, in this study we examine the competitive interactions within and between species with and without AMF. We compare the reactions of two sympatric species that are frequently used to help recover previously degraded.

\section{Materials and methods}

Two tree species with very different reactions to AMF were used in this study, both native to the Atlantic Forests of southern Brazil. Lafoensia pacari has an obligatory association with AMF (Carneiro et al. 1996; Zangaro et al. 2003) while Cabralea canjerana is apparently only marginally responsive to AMF (Pasqualini et al. 2007). Seeds of C. canjerana were sown individually in trays that were divided into $100 \mathrm{ml}$ "cells" while L. pacari was grown in pots of 1.51 , each with 15 seeds. Substrate was a mixture of sand and soil in a ratio of 2:1. Soils were sterilized ( $1 \mathrm{~h}$ autoclave at $120^{\circ} \mathrm{C}$, repeated $24 \mathrm{~h}$ later). The AMF treatment plants were grown in the same previously sterilized soils, but with cultures of the fungus mixed in prior to planting. Fungal cultures include Acaulospora koskei (SPL102), Entrophospora colombiana (SCT115) and Scutellospora heterogama (SCT113), all from the Germplasm Bank of the AMF at the Universidade Regional de Blumenau, in the state of Santa Catarina, in southern Brazil. These fungal isolates were chosen because they have been shown to associate with and promote growth in trees (Stürmer, pers. com.). 
To produce the fungi for the experiment, pure cultures were mixed in sterile soil (sand-soil 2:1) in plastic pots of 1.51 . Around 30 sorghum seeds were planted in each pot. After 4 mos. of greenhouse cultivation, the plants and substrates were dried and the aerial part of the plant and top $2 \mathrm{~cm}$ of substrate were discarded. The roots with the remainder of the soil (the mycorrhizal inoculum) were stored in plastic bags and refrigerated until use.

One month after germination the seedlings were replanted in 100 pots with sterile soil in a 2:1 mixture of sand and soil (red-yellow argisol). Half of the pots had a final density of six individuals per pot (low density) and the other half had 12 individuals per pot (high density). The AMF was innoculated into half the pots of each treatment.

Finally, the proportion of each species in each pot was also varied, following the "Replacement Series" design (Begon et al. 1996). Thus, the proportion of L. pacari and C. canjerana in each pot were $0: 6,2: 4$, $3: 3,4: 2$ and $6: 0$ (in the low density treatment, with and without AMF) and $0: 12,3: 9,6: 6,9: 12$ and $12: 0$ (in the high density treatment, with and without AMF), each of which was replicated five times.

The experiment started in mid September of 2005 and ended in late January, during the hottest part of the year (average temperatura $>20^{\circ} \mathrm{C}$ ). Plants were grown in greenhouses with uncontrolled temperature and lighting. Plants were watered daily ad lib as necessary to avoid water stress. Nutrients were not measured in the soils, but the original material was from the B horizon in red-yellow argisol, known in this region to be naturally low in nutrients.

At harvest after $90 \mathrm{~d}$, plants were carefully removed from the pots and soil in running water. The aerial part was separated from the roots and both were oven dried $\left(60^{\circ} \mathrm{C}\right.$ for $\left.48 \mathrm{~h}\right)$. Plants were then weighed (total dry, roots, stems and leaves) and measured (stem length).

Acrial dry weight was used to determine the influence of the mycorrhiza on growth as the ratio of the difference between those grown without and with $\mathrm{AMF}$ over those grown without AMF as follows: (dry weight with minus dry weight without)/(dry weight without) multiplied by 100 to be represented as a percentage (Plenchette et al. 1983).

Roots were examined in each replica to determine the amount of mycorrhizal association following Koske and Gemma (1989). Roots were immersed in boiling potassium hydroxide solution $(\mathrm{KOH}, 10 \%)$. This was followed by immersion in 3\% hydrogen peroxide solution $\left(\mathrm{H}_{2} \mathrm{O}_{2}\right)$ for $5 \mathrm{~min}$ and washed once again. Roots were then placed for 5-10 min in $1 \%$ hydrochloric acid $(\mathrm{HCl})$ and then colored with by boiling in $0.05 \%$ Trypan Blue for $10 \mathrm{~min}$. They were then washed and stored in a refrigerator until examined. The degree of colonization was measured following Giovanetti and Mosse (1980) using plates with grids in which at the grid intersections the number of points with the fungus and without are counted.

Relative yield was calculated as the ratio of the biomass of plants grown in each treatment to that of plants grown alone. Relative yield curves show the importance of the various variables by being compared to the null model of having been grown alone (Begon et al. 1996). Relative yield greater than the null model suggests that competition is unimportant, while if less than predicted indicates strong competition. Weight of the stem, roots and leaves were compared among treatments, by species by analysis of variance (ANOVA).

\section{Results}

None of the plants grown in sterile soil inadvertently formed a mycorrhizal association. In the AMF treatment in C. canjerana, root colonization was $68-71 \%$ in monoculture while it was $54-69 \%$ when mixed with $L$. pacari. In the AMF treatment in L. pacari root colonization was $50-57 \%$ in monoculture while it was $51-66 \%$ with $C$. canjerana.

Relative yield in Cabralea canjerana declined when associated with AMF $(-27 \%$ at six plants pot $^{-1}$, and $-13 \%$ at 12 plants pot ${ }^{-1}$ ). In contrast, relative yield in $L$. pacari increased with AMF $(293 \%$ at six plants pot ${ }^{-1}, 116 \%$ at 12 plants pot ${ }^{-1}$ ).

When comparing with and without $A M F$, dry weight was similar in both treatments $\left(F_{1,39}=\right.$ $0.810, P=0.374)$. Dry weight was greater without AMF than with in $C$. canjerana $\left(F_{1,19}=8.1, P=0.01\right)$. On the other hand, in Lafoensia pacari dry weight was greatest with AMF $\left(F_{1,19}=78.3, P<0.0001\right.$, Table 1). Plants of $C$. canjerana with AMF were $34 \%$ smaller than those without (Table 1). Plants of L. pacari, with $\mathrm{AMF}$ were $300 \%$ larger than those without (Table ). 
Table 1 Comparisons of shoot and root development ( $\mathrm{g}$ dry weight) between species (ANOVA)

\begin{tabular}{lllll}
\hline Treatment & Leaf & Stem & Root & Total \\
\hline M+ & 0.54 & 0.48 & 0.72 & 1.73 \\
M- & 0.58 & 0.41 & 0.79 & 1.78 \\
M + CC & $0.32 * *$ & $0.32 * *$ & $0.60 * *$ & $1.25 * *$ \\
M CC & 0.59 & 0.43 & 0.86 & 1.88 \\
M + LP & $0.37 * *$ & $0.29 * *$ & $0.32 * *$ & $0.95 * *$ \\
M LP & 0.13 & 0.08 & 0.11 & 0.3 \\
D6 & $0.63 * *$ & $0.49 *$ & $0.87 * *$ & $1.96 * *$ \\
D12 & 0.49 & 0.40 & 0.64 & 1.55 \\
D6 CC & $0.49 *$ & $0.40 *$ & $0.84 * *$ & $1.73 * *$ \\
D12 CC & 0.42 & 0.35 & 0.63 & 1.41 \\
D6 LP & $0.30 * *$ & $0.22^{* *}$ & $0.25 * *$ & $0.72 * *$ \\
D12 LP & 0.20 & 0.15 & 0.17 & 0.53 \\
\hline
\end{tabular}

$D$ total plant density, $M+$ with mycorrhiza, $M-$ without mycorrhiza, CC Cabralea canjerana, LP Lafoensia pacari

$* p<0.05, * * p<0.01$

Density strongly influenced final plant weight (Table 1). At the maximum density of 12 plants pot $^{-1}$, dry weight was $21 \%$ less than that at a density of six plants $\operatorname{pot}^{-1}$ (Table 1 ).

In the mixed species treatments without AMF, dry weight (total, leaf, root) in C. canjerana declined as density of $C$. canjerana increased (Fig. 1). With AMF, on the other hand, dry weight remained relatively constant in the low density treatment (except at the density 6 for roots, Fig. 1c).

The response to density was the opposite in $L$. pacari. Here we found an early increase followed by decline (yet neither a large increase nor large decline) with intraspecific density in the low density treatment without AMF (Fig, 1). Relative yield decreased while density increased in C. canjerana independently of AMF treatment (with AMF, Fig. 2a, c e, without AMF, Fig. 2b, d) and of total density (DT 6, Fig. 2a, b; DT 12 , Fig. 2c, d). However, relative yield was greater in the without $\triangle M F$ treatment. On the other hand, relative yield of $L$. pacari declined (to the proportion LP4:CC2 $)$ both without and with AMF $\left(F_{2,98}=166.4\right.$, $P=0.001, F_{2,98}=2016.0, P=0.001$, Fig. $2 a$ and $b$ respectively), thereby demonstrating inter-specific competition. In the high density treatments none of the relative yield was below the expected values under the null model (Fig. 2c, d).

\section{Discussion}

The response of $L$. pacari to the AMF (root colonization, dry weight) suggests that it is classified as an obligate mycorrhizal symbiont (Siqueira and Franco 1988; Zangaro et al. 2003). On the other hand, C. canjerana is not so easily classified as obligatory or not (as proposed by Siqueira and Franco 1988), because of it was strongly colonized by the fungus although it seemed to be a detrimental association, as dry weight declined in infected plants. This suggests that the fungus is actually a parasite of this species.

Three conditions may cause a detrimental response by the plant to AMF: low light, low temperatures and extremely fertile soil. Low light and temperature can limit photosynthesis with the result that the fungus extracts too much $\mathrm{C}$ from the plant (Smith and Smith 1996). With excessive nutrients, especially $P$, the hyphae do not absorb enough $\mathrm{P}$ and the excess limits plant growth (Smith and Smith 1996). None of these were the case in this experiment, and therefore our results were not due to these kinds of adverse conditions.

Poor growth in the grass Koeleria pyramidata that is facultatively associated with mycorrhizae in competition with the grass Andropogon gerardii that is obligatorily associated with mycorrhiza, shows that the former species is being parasitized by the fungus (Hetrick et al. 1989). Another non-mycorrhizal plant species, Salsola kali, can be invaded by mycorrhizal fungus to the detriment of the plant survival (Allen et al. 1989). Thus, fungal associations are not always symbiotic, but when they are symbiotic, they may become obligatory (Francis and Read 1994).

These kinds of differences may in part explain the results observed in this experiment and the association between the plants and fungus may be a consequence of the conditions in which each species is typically found. For example, L. pacari is a pioneer species with very small seeds while C. canjerana is a secondary species with large seeds. Some studies suggest that in the tropics, early successional species are usually not associated with fungi and in succession are followed by facultative and then obligatory associations (Janos 1980; Siqueira et al. 1998; Zangaro et al. 2003; Pasqualini et al. 2007). In contrast, in temperate latitudes, pioneers are associated with myconhiza and often in low quality soils (Allen and Allen 1990). A study of 80 tropical tree species in different succes- 
Fig. 1 Influence of mycorthizal symbiosis on dry weight of Cabralea canjerana $(C C)$ and Lafoensia pacari $(L P)$ at different densities. $\mathbf{a}$ and $\mathbf{b}$ Leaf dry weight; $\mathbf{c}$ and $\mathbf{d}$ Root dry weight; $\mathbf{e}$ and $\mathbf{f}$ Stem dry weight; $\mathrm{g}$ and h Total dry weight. (1) Low density, (2) High density. w $\mathrm{CC}$ with and $\square$ without AMF; $\Delta$ LP with and $\Delta$ without AMF. Asterisks indicate differences $(P<0.05)$ between AMF treatments
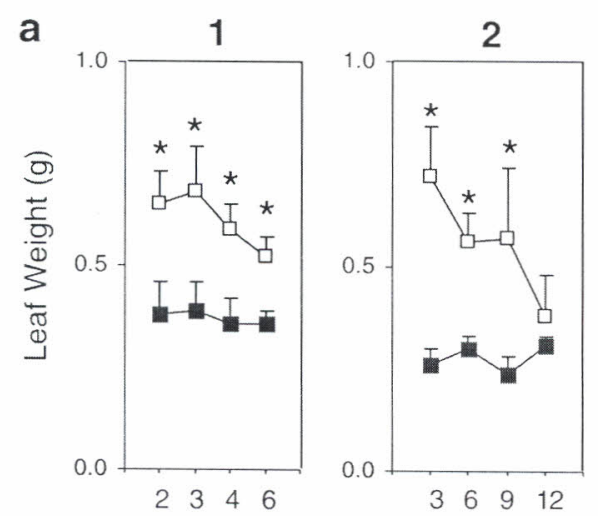

b
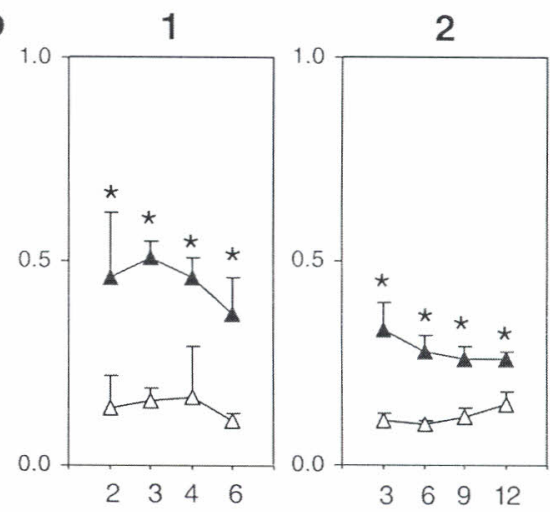

C
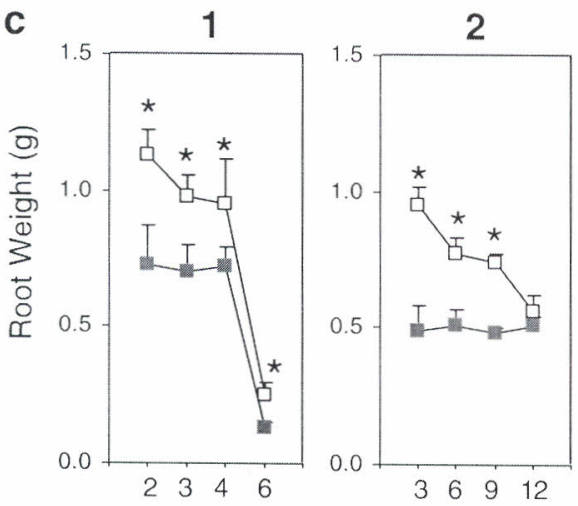

d
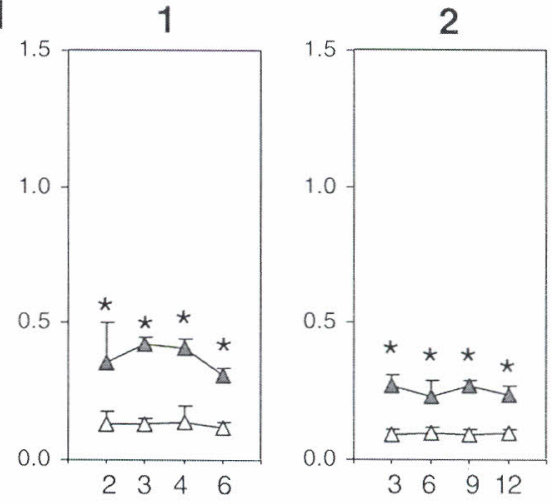

e
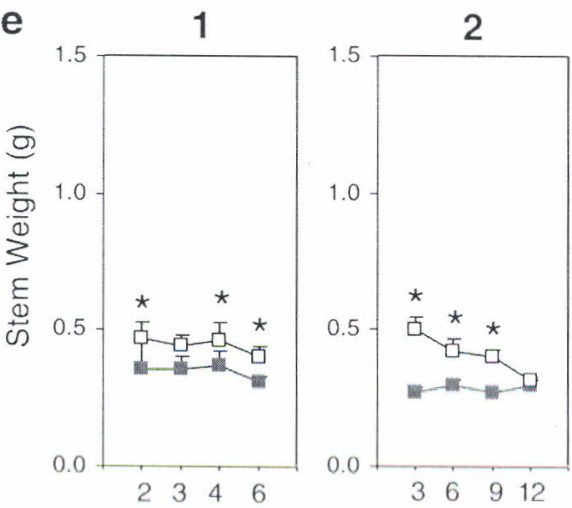

f
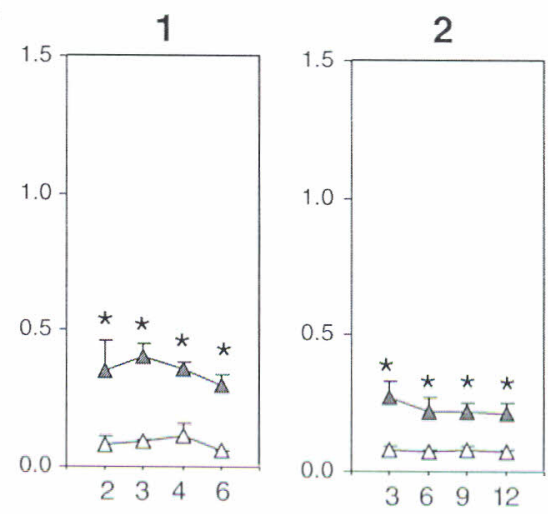

g
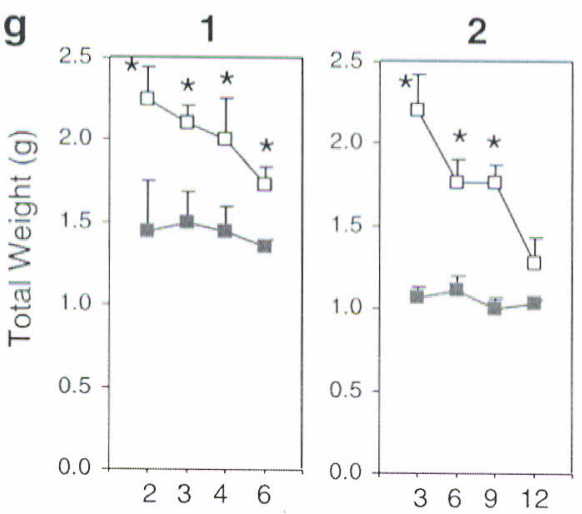

h

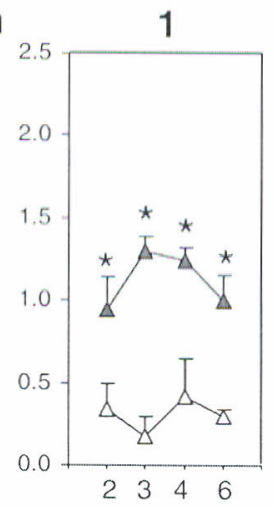

2

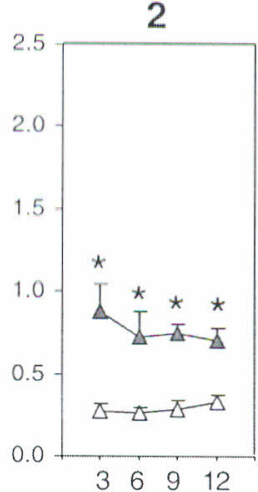



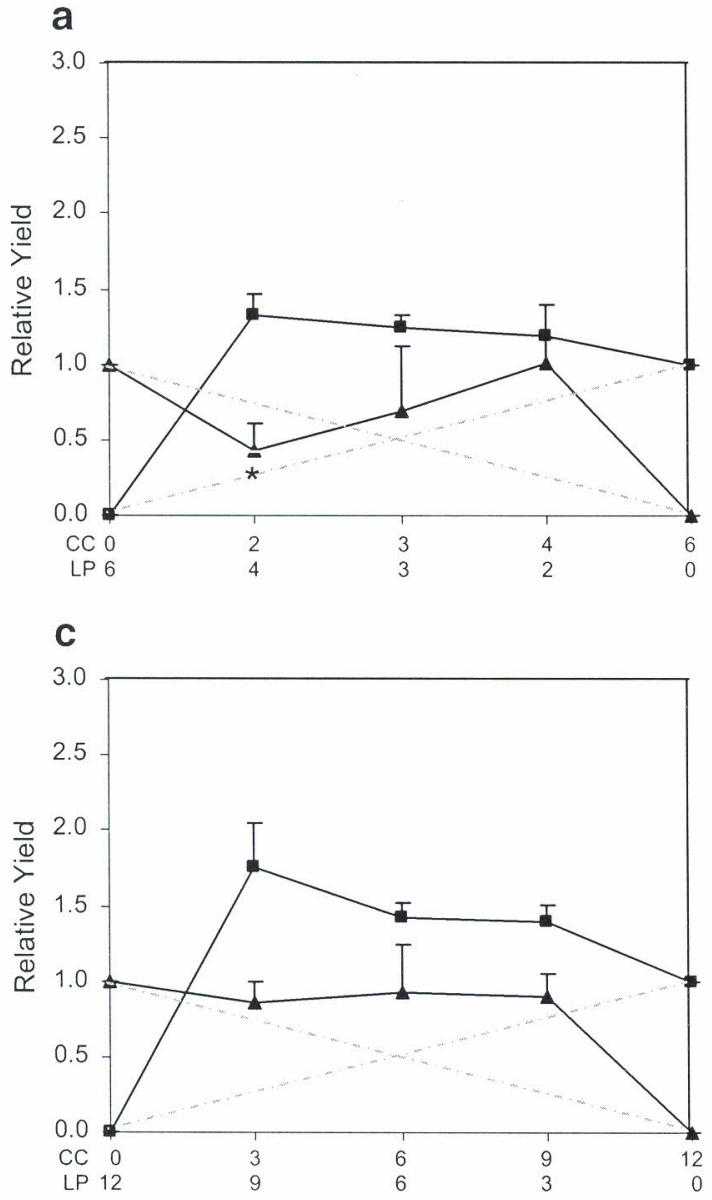

Fig. 2 Relative yield without (a low density, c high density) and with (b-low density, d-high density) AMF. - Lafoensia pacari; - Cabralea canjerana. The lighter

sional stages found strong associations in pioneer species and not so strong in those in later successional stages (Zangaro et al. 2000). This may be in part due to the correlated characteristic of larger seeds (with larger energetic reserves) in later successional stages (Zangaro et al. 200()).

Also, associations with mycorrhiza may become parasitic at particular stages in development (Bethlenfalvay et al. 1982; Koide 1985). Early mycolthizal association may reduce growth in plants soon after germination, since the fungus removes $\mathrm{C}$ necessary for plant growth (Bethlenfalvay et al. 1982; Koide 1985). This was probably not the case here in this experiment, because the time interval was sufficient and the growing conditions were not limiting.

Relative yield of each species in this experiment showed strong competition between the two species
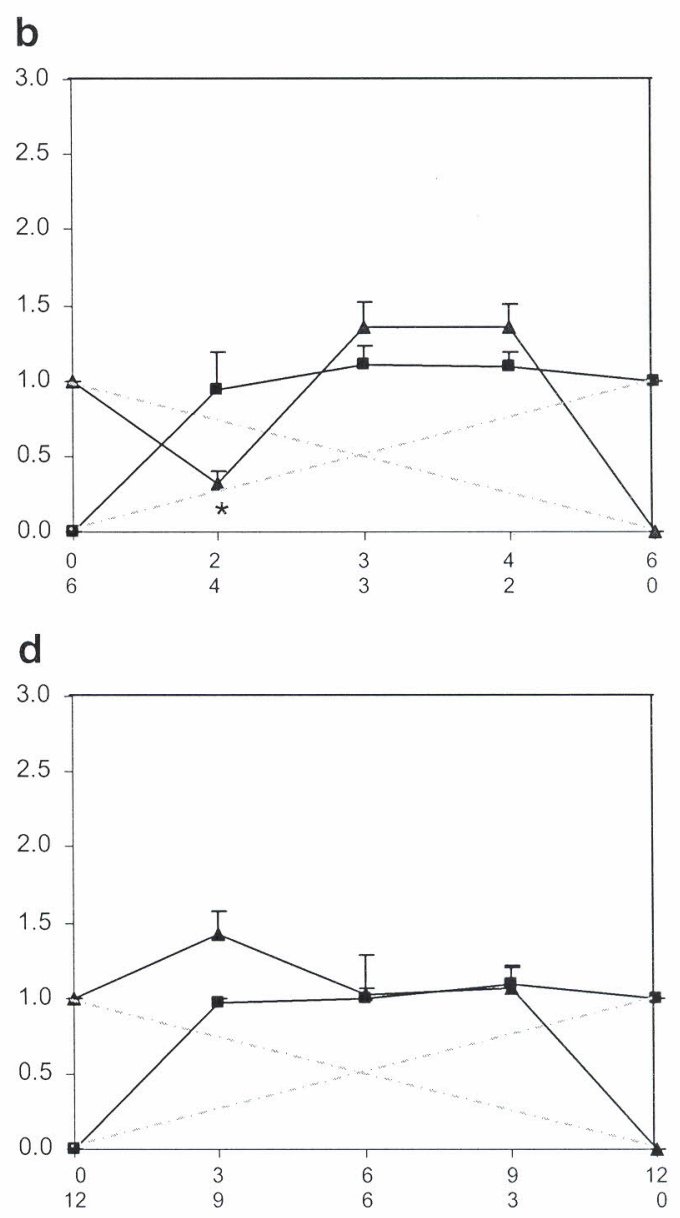

lines indicate the null model. When the observed values lie beneath the line of null model, inter-specific competition occurred. Asterisks indicate $P<0.05$

only at 4:2 (LP 4, CC 2, in the low density treatment), with and without AMF (Fig. 2a e 2b). This may be due to intra-specific competition in $C$. canjerana, that which at low density (two individuals) may impact the growth of L. pacari. Intra-specific competition is apparently important for $C$. canjerana that, due to its larger size, generates a larger impact at higher densities (Fig. 2a, b, c, d). This trend is supported by the observations that relative yield of $C$. canjerana declines with increasing density, independently of treatment. However, it is still possible that interspecific competition may also play a role that is difficult to separate in this experiment.

In the treatments without AMF, the reduction in relative yield of $C$. canjerana due to intra-specific competition favored the increase in relative yield of L. pacari. This would suggest that increasing density 
of $C$ canjerana could cause a reduction in relative yield of $L$. pacari, which in fact did not occur. The reduction in yield of $L$. pacari associated with the increase in yield of $C$. canjerana may be due to attenuation of intra-specific competition in the later species or an increase in intra-specific competition in the former species.

When grown with AMF, while the effect was similar, yield in C. canjerana was less than that without AMF. On the other hand, yield in L. pacari was greater with AMF and tended to increase as density of $C$. canjerana declined. This trend supports the suggestion that intra-specific competition is important. Thus, while inter-specific competition may occur, its effects were not apparent in this experiment-perhaps because intra-specific competition was so strong. Thus, the presence of AMF did not benefit the obligate associate species (L. pacari) to the detriment of the other species ( $C$. canjerana) as was expected.

These results seem to disagree with others, in which AMF favor the competitive qualities of the associated plant species in inter-specific competitive interactions (Allen and Allen 1990; Hartnett et al. 1993; Zobel and Moora 1995). In Centaura jacea and Fragaria vesca as competitors, with AMF, the difference in biomass of each species increased as they grew mycorrhiza, which was suggested to be due to differential response to the fungus by the plants (Zobel and Moora 1995). Therefore, these data supported the hypothesis that AMF may mediate important interactions that determine plant dominance in the field (Zobel and Moora 1995). Similarly, competition between two grasses, one nonmycorrhizal, favored the mycorrhizal species (Allen and Allen 1990).

A possible factor that may explain why intra-specific competition was dominant is the difference in size of the two species. Cabralea canjerana has very large leaves and which may result in competition by shading the other plants, while L. pacari has small leaves and so will not cause a similar effect. This suggests that competitive interactions may be a consequence of characteristics inherent to each species in addition to the influence of other biotic and abiotic factors (Johnson et al. 1997; Sylvia et al. 2001; van der Heijden 2002).

While apparently not important for inter-specific competition, AMF do influence intra-specific competition for both species. The difference in growth in each species when with and without AMF (Fig. 1) show that $C$. canjerana is strongly competitive with itself in the absence of AMF, while L. pacari grows best with AMF. Additionally, dry weight varies little on inoculated soils in $C$. canjerana, while dry weight varies little in $L$. pacari on sterile soils. Thus, growth in each species is linked to its reaction to AMF.

Our results suggest that Lafoensia pacari, while strongly influenced by its AMF association, does not acquire a competitive advantage when in association over Cabralea canjerana (either with AMF or without). Despite this, the AMF seems to accentuate intra-specific interactions for $L$. pacari and to parasitize C. canjerana. By parasitizing C. canjerana, intra-specific competition is reduced.

Thus, we suggest the hypothesis that tree species do not respond in the same way to mycorrhiza as do grasses, in which the species with mycorrhiza has an increased inter-specific competitive edge over species without mycorrhiza. As this experiment was carried out with young trees, the next question is whether AMF actually do influence competitive interactions among adult trees?

Acknowledgements We thank the Universidade Regional de Blumenau (FURB) for its support, as well as its Botany, Biotechnology, Immunology and Zoology laboratories and the Chemistry Department, for their support and use of their facilities. Thanks to professors Geraldo Moretto and Carlos Efrain for their help with statistics. Thanks to the Tutorial Education Program (PET/Biologia) for the financial support and the incentive for research that it enabled. James I. Roper translated this text from the original Portuguese

\section{References}

Allen MF (1996) The ecology of mycorrhizae. Cambridge University Press, Australia

Allen EB, Allen MF (1990) The mediation of competition by mycorrhizae in successional and patchy enviromments. In: Grace JB, Tilman GD (eds) Perspectives on plant competition. Academic, New York, pp 367389

Allen MF, Allen EB, Friese CF (1989) Responses of the nonmycotrophic plant Salsola kali to invasion by vesicular arbuscular mycorrhizal fungi. New Phytol 111:45 49

Begon M, Mortimer M, Thompson DJ (1996) Population ecology. Blackwell Science, Cambridge

Bethlenfalvay GJ, Brown MS, Pacovsky RS (1982) Parasitic and mutualistic associations between a mycorrhizal 
fungus and soybean: development of the host plant. Phytopathology 72:889-893

Carneiro MAC, Siqueira JO, Davide AC, Curi LJGN, Vale FR (1996) Fungo Micorrízico e superfosfato no crescimento de espécies arbóreas tropicais. Scientia Forestalis 50:2136

Chapin FS, Walker LR, Fastie CL, Sharman LC (1994) Mechanisms of primary succession following deglaciation at Glacier Bay, Alaska. Ecol Monogr 64:149-175

Dodd JC, Boddington CL, Rodriguez A, Gonzalez-Chavez C, Mansur I (2000) Mycelium of arbuscular Mycorrhizal Fungi (AMF) from different genera: form, function and detection. Plant Soil 226:131-151

Francis R, Read DJ (1994) The contribuitions of mycorrhizal fungi to the determination of plant community structure. Plant Soil 159:11 25

Giovanetti M, Mosse B (1980) An avaluation of techniques for measuring vesicular-arbuscular mycorrhizal infection in roots. New Phytol 84:489 500

Hart MM, Reader RJ, Klironomos JN (2003) Plant coexistence mediated by arbuscular mycorrhizal fungi. Trends Ecol Evol 18:418 423

Hartnett DC, Wilson GWT (2002) The role of mycorrhizas in plant community structure and dynamics: lessons from grasslands. Plant Soil 244:319-331

Hartnett DC, Hetrick BAD, Wilson GWT, Gibson DJ (1993) Mycorrhizal influence on intra- and interspecific neighbour interactions among co-occuring prairie grasses. J Ecol 81:787-795

Hetrick BAD, Wilson GWT, Hartnett DC (1989) Relationship between mycorrhizal dependency and competitive ability of two tallgrass prairie grasses. Can J Bot 67:2608 2615

Hetrick BAD, Hartnett DC, Wilson GWT, Gibson DJ (1994) Effects of mycorrhizae, phosphorus availabiliy, and plant density on yield relationsships among competing tallgrass prairie grasses. J Bot 72:168-176

Janos DP (1980) Mycorrhizae influence tropical succession. Biotropica 12:56-64

Johnson NC, Graham JH, Smith FA (1997) Functioning of mycorrhizal associations along the mutualism-parasitism continuum. New Phytol 135:575 585

Jones MD, Smith SE (2004) Exploring functional definitions of mycorrhizas always I mutualisms? Can J Bot 82:1089 1109

Khalil S, Loynachan TE, Tabatabai MA (1999) Plant determinants of mycorrhizal dependency in soybean. Agron J 91:135-141

Koide R (1985) The Nature og growth depressions in sunflower caused by vesicular-arbuscular mycorrhizal infection. New Phytol 99:449 462

Koskic RE, Gemma IN (1989) A modified procedure for staining roots to detect $V \wedge$ mycorrhizas. Mycol Res $92: 486-488$

Kytöviita MM, Vestberg M, Tuomi J (2003) A test of mutual aid in common mycorrhizal networks: established vegetation negates benefit in seedlings. Ecology 84:898-906

Marschner H (1995) Mineral nutrition of higher plants. Academic, London

Newsham KK, Fitter AH, Watkinson AR (1995) Arbuscular mycorrhiza protect an annual grass from root pathogenic fungi in the field. J Ecol 83:991-1000
Oliveira RS, Castro PML, Dodd JC, Vosátka M (2005) Synergistic effect of Glomus intraradices and Frankia spp. on the growth and stress recovery of Alnus glutinosa in an alkaline anthropogenic sediment. Chemosphere $60: 1462-1470$

Oliveira RS, Castro PML, Dood JC, Vosátka M (2006) Different native arbuscular mycorrhizal fungi influence the coexistence of two plant species in a highly alkaline anthropogenic sediment. Plant Soil 287:209-221

Ozinga WA, van Andel J, Mcdonnell-Alexander MP (1997) Nutritional soil heterogeneity and mycorrhiza as determinants of plant species diversity. Acta Bot Neerl $46: 237-254$

Pasqualini D. Uhlmann A, Stürmer S (2007) Arbuscular mycorrhizal fungal communities influence growth and phosphorus concentration of woody plants species from the Atlantic rain forest in South Brazil. Forest Ecol Manag 245:148-155

Pedersen CT, Sylvia DM (1996) Mycorrhiza: Ecological implications for plant interactions. In: Mukerji KG (ed) Concepts in mycorrhiza. Kluwer, Dordrecht

Plenchette C, Fortin JA, Furlan V (1983) Growth response of several plants species to mycorrhiza in a soil of moderate $P$ fertility. I. Mycorrhizal dependency under field conditions. Plant Soil 70:191-209

Siqueira JO, Franco AA (1988) Biotecnologia do solo, fundamentos e perspectivas. MEC/ABEAS/ESAL/FAEPE, Brasilia

Siqueira JO, Carneiro MAC, Curi N, Rosado SCS, Davide AC (1998) Mycorrhizal colonization and mycotrophic growth of native woody species as related to successional groups in Southeastern Brazil. Forest Ecol Manage 107:241-252

Smith FA, Smith SE (1996) Mutualism and parasitism: Diversity in function and structure in the "arbuscular" (VA) mycorrhizal symbiosis. Adv Bot Res 22, Academic

Smith SE, Read DJ (1997) Mycorrhizal symbiosis. Academic I, New York

Sylvia DM, Williams SE (1992) Vesicular-arbuscular mycorrhizae and environmental stresses. In: Bethlenfalvay GJ, Linderman RG (cds) Mycorrhizae in sustainable agriculture. ASA, Madison, pp 101 124

Sylvia DM, Alagely AK, Chellemi DO, Demchenko LW (2001) Arbuscular mycorrhizal fungi influence tomato competition with bahiagrass. Biol Fertil Soils 34:448 452

Thingstrup I, Rubaek G, Sibbesen E. Jakobsen I (1998) Flax (Linum usitatissimum L.) depends on arbuscular mycorthizal fungi for growth and P uptake at intermediate but not high soil $\mathrm{P}$ levels in the field. Plant Soi $203: 37-46$

Tilman D (1982) Resource competition and community structure. Princeton University Press, Princeton

van der Heijden MGA (2002) Arbuscular mycorrhizal fungi as a determinant of plant diversity: In search of underlying mechanisms and general principles. In: van der Ileijden MGA, Sanders IR (eds) Mycorrhizal ecology. Springer, Berlin, pp $243-265$

van der Heijden MG, Wiemken A, Sanders IR (2003) Different arbuscular mycorrhizal fungi alter coexistence and resource distribution between co-occurring plant. New Phytol $157: 569-578$ 
Wright SF, Upadhyaya AA (1998) Survey of soils for aggregate stability and glomalin, a glycoprotein produced by hyphae of arbuscular mycorrhizal fungi. Plant Soil 198:97-107

Zangaro W, Bononi VLR, Trufem SFB (2000) Mycorrhizal dependency, inoculum potential and habitat preference on native woody species in South Brazil. J Trop Ecol 16:603621
Zangaro W, Nisizaki SMA, Domingos JCB, Nakano EM (2003 Mycorrhizal response and successional status in 80 woody species from south Brazil. J Trop Ecol 19:315-324

Zobel M, Moora M (1995) Interespecific competition and arbuscular mycorrhiza: importance for the coexistence of two calcareous grassland species. Folia Geobot 30:223 230 